\title{
PENGARUH PRAKTEK PERMAINAN PUZZLE TERHADAP PENINGKATAN PEMAHAMAN PESERTA DIDIK PADA MATERI IKATAN KIMIA DI SMA
}

\author{
Sukarni \\ SMA Negeri 2 Sungai Kakap Kabupaten Kubu Raya \\ Email: sukarnisp12@gmail.com
}

\begin{abstract}
Abstrak
Penulisan Penelitian Tindakan Kelas ini dilatarbelakangi oleh beberapa hal; (1) Mata pelajaran kimia dianggap sulit, (2) Peserta didik malas membaca, (3) Peserta didik kurang mampu menghafal, dan (4) Peserta didik mudah melupakan nama unsur. Tujuan penulisan Penelitian Tindakan Kelas ini adalah; ((1) Agar guru selalu berinovasi dalam meningkatkan strategi dan kualitas pembelajaran di kelas, dan (2) Supaya peserta didik dapat berpikir kritis, kreatif, cermat, percaya diri, dan dapat belajar dengan gembira dan menyenangkan. Penggunaan media pembelajaran puzzle adalah upaya untuk meningkatkan kualitas pelajaran kimia, di mana peserta didik melakukan sebagian besar kegiatan selama proses pembelajaran. Peserta didik belajar aktif, gembira, bekerja sama, saling membantu, saling memacu, berani bertanya dan berani mengajukan pendapat. Kesimpulan; Dengan belajar menggunakan media pembelajaran puzzle Tabel Periodik Unsur, peserta didik bisa mengingat dan membedakan jenis unsur, sehingga memudahkan peserta didik dalam mengelompokkan unsur, menuliskan senyawa yang berikatan ion dan kovalen.
\end{abstract}

\section{Kata Kunci: Media Pembelajaran Puzzle, Tabel Periodik Unsur, Model Pembelajaran Kooperatif, Materi Pelajaran Ikatan Kimia SMA Kelas X.}

\section{PENDAHULUAN}

Mata pelajaran kimia, seringkali dianggap mata pelajaran yang sulit dan tidak menarik. Oleh sebab itu, guru harus berupaya agar pelajaran ini menjadi menarik dan menyenangkan bagi peserta didik. Salah satu upaya untuk meningkatkan kualitas pelajaran Kimia adalah dengan menggunakan pembelajaran aktif, di mana peserta didik melakukan sebagian besar kegiatan selama proses pembelajaran. Belajar aktif merupakan langkah cepat, menyenangkan, mendukung dam menarik hati dalam belajar (Melvin, 2001). Proses belajar aktif berpusat pada peserta didik, selama proses pembelajaran yang paling penting peserta didik dapat memecahkan masalah sendiri, menemukan contoh-contoh, mencoba keterampilan baru, dan melaksanakan tugas tergantung pada pengetahuan yang telah mereka miliki atau yang akan dicapai

Penerapan metode ini akan dinilai berhasil apabila dihasilkan peserta didik yang terlibat berpikir aktif dalam setiap kegiatan kelas, berani mengajukan pertanyaan dan jawabannya, maupun mengajukan gagasan dan pendapat, mampu dan berani menilai hasil/ membuktikan sesuatu, serta mampu memecahkan masalah yang dihadapi.

Pelajaran kimia secara umum sulit dipahami peserta didk, termasuk materi yang berkaitan dengan ikatan kimia. Sebelum masuk materi ikatan kimia, peserta didik terlebih dahulu harus bisa mengelompokkan unsur-unsur ke dalam kelompok unsur-unsur logam dan kelompok unsur-unsur nonlogam. Berdasarkan pengalaman selama mengajar bertahun-tahun, peserta didik selalu dengan mudah melupakan unsur-unsur dan senyawa, meskipun unsur-unsur dan senyawa tertentu selalu menjadi contoh di setiap penjelasan. Hal ini terbukti dari setiap ulangan semester yang rata-rata nilainya $50 \%$ berada di bawah nilai 70.0 sedangkan KKM pelajaran Kimia di SMA Negeri 2 Sungai Kakap adalah 70,0 (tujuh).

Berikut daftar nilai akhir semester ganjil tahun pelajaran 2017/2018, nilai pembelajaran kimia peserta didik kelas X MIA SMA Negeri 2 Sungai Kakap, yang tuntas hanya $50 \%$, yang tidak tuntas juga $50 \%$. Untuk lebih rinci, bisa dilihat pada tabel berikut: 
Tabel 1. Hasil Penilaian Semester 1 Tahun 2017/2018

\begin{tabular}{ccc}
\hline Nomor & Ragam Data & Skor/Jumlah \\
\hline 1 & Banyaknya peserta didik & 34 orang \\
\hline 2 & Siswa perempuan & 23 orang \\
\hline 3 & Siswa laki-laki & 11 orang \\
\hline 4 & Banyaknya yang tuntas & 17 orang $(50 \%)$ \\
\hline 5 & Banyaknya yang tidak tuntas & 17 orang $(50 \%)$ \\
\hline 6 & Skor tertinggi & 80 \\
\hline 7 & Skor terendah & 25 \\
\hline 8 & Rata-rata & 52,5 \\
\hline
\end{tabular}

Berdasarkan tabel 1 di atas, dapat diuraikan bahwa siswa yang tuntas hanya 17 orang $(50 \%)$, sedangkan yang tidak tuntas masih separuhnya, yaitu 17 orang (50\%). Tingkat ketuntasan tergolong sangat rendah. Bila dikaji penyebabnya, motivasi belajar peserta didik masih sangat rendah, karena dilihat dari rata-rata nilai yang hanya 52,5. Masih jauh dari KKM yang ditetapkan dengan nilai 70 . Rentang nilai antara peserta didik dengan nilai tertinggi 80 dan dengan peserta didik dengan nilai terendah 25, sangat jauh. Hal ini perlu ada upaya untuk meningkatkan nilai peserta didik yang terendah, agar rentang perbedaan data nilai tidak terlalu jauh.

Dalam usaha meningkatkan kualitas belajar mengajar, guru harus selalu berupaya menemukan tehnik, agar minat belajar peserta didik terhadap mata pelajaran kimia yang dianggap sulit, menjadi pelajaran yang menarik dan menyenangkan. Belajar aktif merupakan langkah cepat, menyenangkan, mendukung dan menarik hati dalam belajar (Melvin, 2001). Proses belajar aktif berpusat pada peserta didik, selama proses pembelajaran yang paling penting peserta didik dapat memecahkan masalah sendiri, menemukan contoh-contoh, mencoba keterampilan baru, dan melaksanakan tugas tergantung pada pengetahuan yang telah mereka miliki atau yang akan dicapai.

Salah satu upaya yang dapat dilakukan oleh penulis adalah berinovasi menciptakan media pembelajaran yang sesuai dengan kebutuhan untuk memahami materi ikatan kimia. Membuat puzzle tabel periodik unsur adalah usaha yang dilakukan oleh penulis, agar peserta didik mudah mengingat letak unsurunsur di dalam tabel periodik unsur. Unsurunsur apa saja yang termasuk unsur logam, dan unsur-unsur apa saja yang termasuk unnsur non logam. Selanjutnya, dengan bermain puzzle unsur secara berkelompok, peserta didik bisa saling membantu dalam menentukan letak unsur, sesuai kelompoknya masing-masing.

Puzzle tabel periodik unsur akan dibuat peserta didik sendiri yang bermanfaat dalam membantu peserta didik dalam melaksanakan pengelompokkan unsur-unsur ke dalam unsur logam dan unsur nonlogam. Bahannya dari busa steroform yang berukuran $50 \mathrm{~cm}$ x $100 \mathrm{~cm}$. Peserta didik di bagi kedalam kelompok kecil, 5 orang perkelompok. Secara berkelompok siswa membuat puzzle dan memainkannya bersamasama dalam pelajaran kimia, materi ikatan kimia.

Setelah puzzle selesai dibuat, maka peserta didik memainkannya secara berkelompok. Peserta didik bekerja secara tim, menyusun kartu unsur ke dalam puzzle sesuai perintah guru, dengan waktu yang telah ditentukan. Saat menyusun kartu, siswa bersaing antar kelompok dalam menyelesaikan tugasnya. Kelompok yang tercepat dalam menyusun kartu, maka akan dapat nilai tertinggi. Dengan menggunakan inovasi media pembelajaran puzzel tabel periodik unsur, penulis yakin, bisa membuat peserta didik mengingat lebih lama nama-nama unsur. Dengan demikian siswa mudah membuat dan menulis ikatan kimia, baik ikatan ion maupun ikatan kovalen.

Susilowarno : 2007, mengatakan kelebihan penerapan inovasi pembelajaran seperti ini adalah memberi kesempatan peserta didik untuk bertanya, berdiskusi, menyelidiki, bereksperimen dalam suasana yang aktif, inovatif, kreatif, efektif dan menyenangkan. Media pembelajaran yang digunakan dapat memberikan pengalaman konkret, memotivasi peserta didik belajar, serta mempertinggi daya serap dan retensi belajar siswa.

Model Pembelajaran yang digunakan dalam pembuatan dan permainan puzzle ini adalah model pembelajaran Cooperative Learning. Model pembelajaran ini merupakan strategi 
pembelajaran yang menitikberatkan pada pengelompokan pesserta didik dengan tingkat kemampuan akademik yang berbeda ke dalam kelompok-kelompok kecil (Saptono, 2003:32). Kepada peserta didik diajarkan keterampilanketerampilan khusus agar dapat bekerja sama dengan baik dalam kelompoknya, seperti menjelaskan kepada teman sekelompoknya, menghargai pendapat teman, berdiskusi dengan teratur, peserta didilk yang pandai membantu yang lebih lemah, dan lain sebagainya.

Strategi pembelajaran dengan kooperatif learning dipakai karena untuk memberikan pemahaman kepada peserta didik tentang arti pentingnya kerjasama kelompok namun tetap memperhatikan terhadap usaha individual. Hal ini sesuai dengan sifat dan kodrat manusia sebagai mahkluk sosial. Selain itu bila dikaitkan dengan profesi dalam bidang teknologi informasi yang sering bekerja secara kelompok atau tim. Oleh karena itu perlu kiranya dalam pembelajaran diberikan pemahaman tentang arti pentingnya kerjasama dalam kelompok.

Sedangkan menurut Lundgren (Sukarmin, 2002:2), Unsur-unsur dasar yang perlu ditanamkan pada diri peserta didik agar $\underline{\text { Model }}$ Pembelajaran Kooperatif atau Cooperative Learning lebih efektif adalah sebagai berikut : (1) Peserta didik harus memiliki persepsi bahwa mereka "tenggelam atau berenang bersama"; (2) Peserta didik memiliki tanggung jawab terhadap temannya dalam kelompoknya, disamping tanggung jawab terhadap diri sendiri, dalam mempelajari materi yang dihadapi; (3) didik harus berpandangan bahwa mereka semuanya memiliki tujuan yang sama; (4) Peserta didik harus membagi tugas dan berbagi tanggung jawab sama besarnya diantara anggota kelompok; (5) Peserta didik akan diberikan suatu evaluasi atau penghargaan yang akan ikut berpengaruh terhadap evaluasi seluruh anggota kelompok; (6) Peserta didik berbagi kepemimpinan sementara mereka memperoleh keterampilan bekerja sama selama belajar; (7) Peserta didik akan diminta mempertanggungjawabkan secara individual materi yang ditangani dalam kelompok kooperatif.

\section{METODE PENELITIAN}

Penelitian ini merupakan Penelitian Tindakan Kelas (PTK) yang dilakukan oleh guru mata pelajaran Kimia di SMA Negeri 2 Sungai Kakap. Dalam penelitian ini terdiri dari beberapa siklus, masing-masing siklus terdiri dari 2 kali pertemuan. Setiap tahapan siklus terdiri dari perencanaan, pelaksanaan, observasi, refleksi terhadap tindakan. Hasil refleksi siklus I digunakan untuk perbaikan rencana tindakan pada siklus berikutnya

Penelitian Tindakan Kelas ini dilaksanakan di kelas X MIA SMA Negeri 2 Sungai Kakap Kabupaten Kuburaya pada semester ganjil tahun pelajaran 2017/2018 pada materi ikatan kimia. Instrumen dalam penelitian ini adalah : (1) Rencana Pembelajaran (RPP), dalam penelitian ini RPP yang digunakan menggunakan metode pembelajaran Cooperative Learning. (2) Pelaksanaan pembelajaran adalah semua langkah kegiatan pembelajaran dari beberapa siklus yang menggunakan metode pembelajaran Cooperative Learning. (3) Lembar observasi, digunakan sebagai acuan untuk melakukan observasi/pengamatan guna memperoleh data yang diinginkan. Lembar observasi yang digunakan dalam penelitian ini adalah lembar observasi guru dalam proses pembelajaran kimia dengan menggunakan Cooperative Learning. (4) Soal Tes, Digunakan untuk mengetahui peningkatan hasil belajar peserta didik terhadap materi yang dipelajari. Tes yang diberikan kepada peserta didik meliputi posttest tanya jawab dan kuisioner dari setiap siklus. Soal tes yang digunakan dalam penelitian ini adalah tes tertulis yang berbentuk essay. Tes bentuk essay ini digunakan sejalan dengan pendapat Sudjana (1999: 36) yang menyatakan "melalui tes essay ini para pesrta didik dapat mengungkapkan aspek kognitif, menyusun dan mengekspresikan gagasannya. Dari gagasan peserta didik, guru secara tidak langsung melihat proses berpikir peserta didik dalam memecahkan masalah". Sebelum penulisan butir soal maka disusun kisikisi terlebih dahulu, kemudian kunci jawaban, dan pedoman penskoran.

Sumber data dalam penelitian ini terdiri dari beberapa sumber, yakni peserta didik, guru, dan teman sejawat serta kolaborator. Teknik pengumpulan data dalam penelitian ini adalah tes observasi, wawancara dan diskusi. Alat pengumpulan data dalam penelitian ini adalah kertas soal, kertas kuisioner, puzzle, kumpulan nilai hasil diskusi, sikap saat bekerja sama dan keaktifan peserta didik saat proses pembelajaran. Indikator kerja peserta didik; (1) tes: rata-rata nilai ulangan harian, (2) Observasi: keatifan peserta didik dalam proses belajar mengajar. Indikator kerja guru; (1) dokumentasi : kehadiran peserta didik, (2) observasi: hasil obeservasi. Analisis Data. Data yang 
dikumpulkan pada setiap kegiatan obeservai pelaksanaan siklus penelitian dianalisis secara deskriptif dengan menggunakan teknik presentase untuk melihat kecendrungan yang terjadi dalam kegiatan pembelajaran

\section{HASIL DAN PEMBAHASAN}

Pada kondisi awal hasil belajar rendah, minat peserta didik dalam mengikuti pembelajaran kimia masih kurang, peserta didik belum berani mengajukan pertanyaan, susah berlatih soal, tidak berami mengemukakan pendapat dan kurang aktif.

Siklus 1

Perencanaan (Planning). Meliputi: (1) Guru melakukan analisis kurikulum untuk melakukan standar kompetensi dan kompetensi dasar yang akan disampaikan kepada peserta didik; (2) Membuat rencana pembelajaran; (3) Membuat instrumen yang dibuat dalam siklus PTK; (4) Menyusun alat evaluasi pembelajaran

Pelaksanaan (Action). Pada saat awal siklus pertama pelaksanaan belum sesuai dalam keaktifan dan hasil belajar peserta didik. Hal ini disebabkan karena: (1) Komunikasi yang bersifat satu arah yang didominasi oleh guru; (2)
Peserta didik belum terbiasa dengan istilahistilah asing dan peserta didik tidak langsung kepada objek yang dipelajari sehingga peserta didik mengalami kesulitan dalam memahami penulisan ikatan ion dan ikatan kovalen. Untuk mengatasi permasalahan tersebut guru merencanakan perubahan metode pengajaran dengan praktek membuat puzzel Tabel Peiodik Unsur

Observasi dan Evaluasi (Observation and Evaluation). Meliputi: (1) Pengamatan terhadap kegiatan belajar mengajar; (2) Pada awal pembelajaran kegiatan belajar didominasi oleh guru, komunikasi bersifat satu arah. Di akhir pembelajaran baru ada beberapa peserta didik yang bertanya; (3) Pengamatan terhadap peserta didik. Guru memberi petunjuk bagaimana menggunakan media dalam menghafal letak unsur pada tabel. Peserta didik membaca dan menghafal unsur-unsur dalamTabel Periodik Unsur yang ada. Sebagian besar peserta didik tampak antusias dalam membaca dan menghafal unsur pada Tabel Periodik Unsur. Namun ada juga peserta didik yang asik berbicara dengan teman sebangkunya. Selebihnya, masih tak bereaksi atau diam.

Tabel 2. Rekapitulasi Perolehan Skor Aktivitas Peserta Didik dalam Tanya Jawab

\begin{tabular}{lcc}
\hline Ketercapaian & Jumlah peserta didik & Persentase \\
\hline Tuntas Belajar & 29 & $85 \%$ \\
\hline Tidak Tuntas Belajar & 5 & $15 \%$ \\
\hline
\end{tabular}

Dari hasil pengamatan penulis, aktivitas peserta didik dalam kegiatan belajar diperoleh nilai terendah $56 \%$ dan nilai tertinggi $81 \%$. Berdasarkan indicator keberhasilan nilai aktivitas peserta didik adalah $66 \%$. Jadi masih ada 5 peserta didik yang belum mencapai KKM.

Hal ini disebabkan karena peserta didik merasa sulit mengingat unsur yang termasuk logam atau nonlogam, sehingga kesulitan memahami proses serah terima elektron dan penggunaan sepasang elektron secara bersama- sama. Selain itu, beberapa peserta didik masih belum terlibat secara penuh, sehingga pemahaman akan ikatan kimia masih jauh.

Berdasarkan hasil kuis peserta didik diperoleh data bahwa nilai yang terendah adalah 58 dan nilai tertinggi 83. Dari data tersebut menunjukkan ada 16 peserta didik yang nilainya belum mencapai KKM. Pengamatan kegiatan belajar mengajar dilakukan oleh teman sejawat, yang mengajar mata pelajaran yang masih linier, dengan penulis.

Tabel 3. Hasil Pengamatan Teman sejawat Terhadap aktivitas di kelas

\begin{tabular}{clc}
\hline No & \multicolumn{1}{c}{ Kegiatan } & Hasil \\
\hline 1 & Guru memberi arahan materi yang dipelajari pada hari itu & 3 \\
\hline 2 & Situasi kelas aktif dan kondusif & 2 \\
\hline 3 & Guru memonitor/ mengevaluasi kegiatan siswa & 2 \\
\hline 4 & Guru menguasai materi yang dipelajari & 3 \\
\hline
\end{tabular}




\begin{tabular}{lll}
\hline 5 & Dalam proses KBM terjadi interaksi guru dan siswa & 2 \\
\hline 6 & Sikap dan penampilan guru dalam mengajar & 3 \\
\hline 7 & Penggunaan bahasa Indonesia yang benar dalam penyampaian materi & 3 \\
\hline 8 & Guru memberi penilaian di akhir pelajaran & 3 \\
\hline & & $65 \%$
\end{tabular}

Keterangan : $1=$ kurang $2=$ sedang $3=$ baik $4=$ sangat baik

Berdasarkan data pengamatan, persentasi aktivitas guru dalam pembelajaran rata-rata sebesar 65\%. Dari data ini munujukkan kemampuan dalam melaksanakan pembelajaran belum optimal, karena pembelajaran didominasi oleh guru.

Refleksi (Reflection). Dari hasil pengamatafan dari keaktfan peserta didik dalam KBM, hasil kuisioner dan keakifan guru maka dapat disimpulkan bahwa penyampaikan materi secara monoton dan terjadi komunikasi satu arah, sehingga hanya ada beberapa peserta didik yang aktif dan faham. Namun beberapa peserta didik yang lain, meski memperhatikan penjelasan guru, tetapi tetap sulit memahami materi ikatan kimia dengan jelas. Bahkan beberapa peserta didik kurang bersemangat dan putus asa, sehingga tertidur.

Berdasarkan dari data tersebut guru menganalisis perlu adanya metode baru, agar guru tidak monoton, sibuk sendiri sehingga peserta didik tidak terlibat dalam pembelajaran. Peserta didik perlu pembelajaran berlangsung dua arah, yang membuat semua peserta didik terlibat secara aktif

\section{Siklus 2 \\ Pertemuan 1}

Perencanaan (Planning). Meliputi: (1) Guru melakukan analisis kurikulum untuk mengetahui kompetensi dasar yang akan disampaikan kepada peserta didik dengan menggunakan media praktek pembuatan puzzel dari bahan steroform; (2) Membuat Rencana Pembelajaran; (3) Membuat Lembar Kerja Siswa (LKS); (4) Membuat instrument yang digunakan dalam siklus PTK; (5) Menyusun alat evaluasi pembelajaran.

Pelaksanaan (Acting). Meliputi: (1) Guru menjelaskan metode yang dipakai adalah praktek membuat puzzel Tabel Periodik Unsur; (2) Guru menjelaskan secara umum cara membuat puzzel Tabel Periodik, lalu memberi petunjuk bagaimana cara bermain menyusun keping unsur ke dalam Tabel; (3) Guru membagi kelas menjadi 7 kelompok. Setiap kelompok diberi tugas membuat puzzel Tabel Periodik Unsur; (4) Peserta didik membuat model puzzel

Tabel Periodik dengan bimbingan guru; (5) Setelah selesai membuat puzzel, peserta didik menyusun keping unsur ke dalam ruang puzzel Tabel Periodik Unsur, berdasarkan instruksi guru. Peserta didik berlomba dalam hitungan waktu, siapa yang tercepat menyusun keping unsur; (6) Setelah peserta didik hafal, dan bisa membedakan unsur logam dan nonlogam, maka mereka mulai diarahkan untuk membuat ikatan kimia. Guru menjelaskan dengan memberi beberapa contoh. Kemudian, peserta didik diinstruksikan untuk membuat 5 ikatan ion dan 5 ikatan kovalen; (7) Selanjutnya pemberian penguatan dan kesimpulan secara bersama-sama

Pengamatan (observation). Meliputi: (1) Situasi kegiatan belajar mengajar. Kegiatan belajar berjalan aktif, adalah ketika seluruh peserta didik melakukan praktek membuat puzzel Tabel Periodik Unsur; (2) Keaktifan peserta didik dalam praktek. Masing-masing peserta didik berperan aktif dalam membuat media puzzel dalam kelompok masing-masing. Pada saat akan membuat puzzel sebagian peserta didik berkreatifitas untuk membuat puzzel namun ada beberapa peserta didik yang bekerja sambil bergurau sehingga waktu pembuatan media puzzel memakan waktu cukup lama. Berikut ini data perolehan skor aktivitas peserta didik dalam praktek membuat puzzle; (3) Keaktifan peserta didik dalam menulis ikatan kimia. Pelaksanaan diskusi membuat ikatan ion dan kovalen, hanya dapat dilakukan dua kali saja karena waktu yang tidak mencukupi. Namun peserta didik kelihatan antusias sekali.

Berdasarkan hasil data kuisioner didapatkan bahwa nilai terendah mencapai 72 dan nilai tertinggi mencapai 90. Sedangkan rata-rata nilai adalah 78,25. Hal ini menunjukkan bahwa nilai kuisioner peserta didik semuanya sudah mencapai KKM. Guru menjelaskan tata cara membuat puzzel Tabel Periodik Unsur dari steroform, kemudian guru memantau seluruh siswa dalam membuat puzzel Tabel Periodik Unsur dari steroform . Setelah selesai membuat puzzel guru mengarahkan peserta didik untuk tukar berlomba menyusun keping unsur ke dalam ruang Tabel Periodik Unsur. 
Tabel 4. Adapun Data Pengamatan Terhadap Guru Saat Pembuatan Media Puzzel Tabel Periodik Unsur Dari Steroform (Diisi Mitra)

\begin{tabular}{clc}
\hline No & \multicolumn{1}{c}{ Kegiatan } & Hasil \\
\hline 1 & Guru memberi arahan materi yang dipelajari pada hari itu & 4 \\
\hline 2 & Situasi kelas aktif dan kondusif & 3 \\
\hline 3 & Guru memonitor/ mengevaluasi kegiatan peserta didik & 3 \\
\hline 4 & Guru menguasai materi yang dipelajari & 4 \\
\hline 5 & Dalam proses PBM terjadi interaksi guru dan peserta didik & 3 \\
\hline 6 & Sikap dan penampilan guru dalam mengajar & 4 \\
\hline 7 & Penggunaan bahasa Indonesia yang benar dalam penyampaian materi & 4 \\
\hline 8 & Guru memberi penilaian di akhir pelajaran & 3 \\
\hline & & $87,5 \%$
\end{tabular}

Keterangan : $1=$ kurang $2=$ sedang $3=$ baik $4=$ Sangat baik

Berdasarkan data pengamatan aktivitas guru yang diisi oleh teman sejawat diperoleh persentasi keaktifan guru adalah $87,5 \%$. Hal ini menunjukkan bahwa guru sudah mencapai keaktifan normal di atas $66 \%$.

Refleksi (reflection). Dalam tahapan refleksi guru dan teman sejawat melakukan analisis data dengan melakukan kategorisasi dan penyimpulan data yang telah terkumpul dalam tahapan pengamatan. Dalam tahapan refleksi guru juga melakukan evaluasi terhadap kekurangan atau kelemahan dari implementasi tindakan sebagai bahan pertimbangan untuk perbaikan dalam pertemuan berikutnya.

\section{Pertemuan 2}

Seperti halnya pertemuan pertama dalam siklus kedua, pertemuan kedua terdiri dari perencanaan, pelaksanaan, pelaksanaan, pengamatan dan refleksi. Perencanaan (Planning). Tim Peneliti membuat rencana pembelajaran berdasarkan hasil refleksi pada siklus pertama dan siklus kedua pada pertemuan pertama.

Pelaksanaan (acting) Meliputi: (1) Guru menjelaskan tujuan pembelajaran tentang puzzel Tabel Periodik Unsur dari steroform; (2) Guru menginstruksikan peserta didik untuk menyusun keping unsur ke dalam ruang puzzle secara berkelompok. Hal ini di lakukan berulang kali, sehingga peserta didik bisa membedakan unsur logam dan nonlogam; (3) Setelah itu, peserta didik di arahkan untuk menulis ikatan kimia. Mereka diberi tugas untuk membuat 5 ikatan ion, dan 5 ikatan kovalen.

Pengamatan (observation). Guru dan teman sejawat melakukan pengamatan terhadap aktivitas

Tabel 5. Hasil Penilaian Guru dan Teman Sejawat Terhadap Aktivitas Peserta Didik

\begin{tabular}{llcccc}
\hline No & Nama peserta didik & $\begin{array}{c}\text { Keaktifan dalam proses } \\
\text { menulis ikatan ion dan } \\
\text { kovalen }\end{array}$ & Skor ideal Persentasi & Keterangan \\
\hline 1 & A B & 12 & 16 & $75 \%$ & \\
\hline 2 & A M & 13 & 16 & $81 \%$ & \\
\hline 3 & A R & 11 & 16 & $69 \%$ & Terendah \\
\hline 4 & As & 11 & 16 & $69 \%$ & \\
\hline 5 & Ay & 11 & 16 & $69 \%$ & \\
\hline 6 & A F & 12 & 16 & $75 \%$ & \\
\hline 7 & B R & 12 & 16 & $75 \%$ & \\
\hline 8 & D I & 12 & 16 & $75 \%$ & \\
\hline 9 & D R A & 11 & 16 & $69 \%$ & \\
\hline 10 & De & 15 & 16 & $93 \%$ & Tertinggi \\
\hline 11 & D P N & 12 & 16 & $75 \%$ & \\
\hline 12 & D E & 12 & 16 & $75 \%$ & \\
\hline
\end{tabular}




\begin{tabular}{lllll}
\hline 13 & D A & 11 & 16 & $69 \%$ \\
\hline 14 & Fa & 11 & 16 & $69 \%$ \\
\hline 15 & F Y & 14 & 16 & $88 \%$ \\
\hline 16 & I S & 14 & 16 & $88 \%$ \\
\hline 17 & Kh & 13 & 16 & $81 \%$ \\
\hline 18 & Kk & 11 & 16 & $69 \%$ \\
\hline 19 & Kr & 14 & 16 & $88 \%$ \\
\hline 20 & Li & 12 & 16 & $75 \%$ \\
\hline 21 & M Z & 12 & 16 & $75 \%$ \\
\hline 22 & M S & 13 & 16 & $81 \%$ \\
\hline 23 & M A & 11 & 16 & $69 \%$ \\
\hline 24 & N S & 12 & 16 & $75 \%$ \\
\hline 25 & Na & 13 & 16 & $81 \%$ \\
\hline 26 & N A A & 14 & 16 & $88 \%$ \\
\hline 27 & P D N & 14 & 16 & $88 \%$ \\
\hline 28 & R A J & 12 & 16 & $75 \%$ \\
\hline 29 & Ri & 13 & 16 & $81 \%$ \\
\hline 30 & R R & 12 & 16 & $75 \%$ \\
\hline 31 & R W & 14 & 16 & $88 \%$ \\
\hline 32 & S I Y & 13 & 16 & $81 \%$ \\
\hline 33 & Sup & 12 & 16 & $75 \%$ \\
\hline 34 & Sum & 12 & 16 & $75 \%$ \\
\hline & & & & \\
\hline
\end{tabular}

Dari hasil pengamatan pada siklus 2, aktivitas peserta didik dalam membuat ikatan ion 93\% (paling tinggi) dan ikatan kovalen 69\% (paling rendah). Hal ini menunjukkan bahwa peserta didik sudah memahami proses penulisan ikatan kimia.

Refleksi (reflection). Guru dan teman sejawat melakukan refleksi terhadap pelaksanaan siklus kedua pada pertemuan kedua. (1) Peserta didik telah memahami unsur logam, nonlogam, dan bisa menulis serta sudah faham perbedaan antara ikatan ion dan kovalen; (2) Seluruh peserta didik aktif dalam pembelajaran.Guru berperan aktif dalam pembelajaran dengan metode praktek membuat puzzle Tabel Periodik Unsur dari steroform

Hasil dari kegiatan ini cukup baik dan memuaskan. Hal ini dibuktikan dari hasil angket yang diberikan peserta didik, tanggapan dari rekan/ mitra, dan nilai ulangan harian peserta didik.(1) Nilai Ulangan Harian. Dari hasil nilai ulangan harian terbukti bahwa kegiatan praktek dan menulis ikatan kimia mampu menuntaskan kegiatan belajar. Nilai ketuntasan klasikal peserta didik sebesar 77, $4 \%$ melebihi standar indikator keberhasilan yang sudah ditetapkan di awal penelitian.; (2) Angket instrumen Keaktifan peserta didik dan tanggapan terhadap penerapan sistem pembelajaran inovatif (permainan media puzzle Tabel Periodik Unsur dari steroform ). Dari angket Instrumen keaktifan peserta didik dan tanggapan terhadap penerapan sistem pembelajaran membuat puzzle Tabel Periodik Unsur dari steroform diperoleh gambaran sebagai berikut: Perubahan suasana pembelajaran peserta didik secara umum menjadi baik dan kondusif. Perubahan suasana belajar ini dapat dibuktikan dengan tingginya nilai dari jawaban angket. Berdasarkan jawaban soal dalam angket tentang ketertarikan belajar dan menumbuhkan semangat, ternyata $71,3 \%$ menyatakan setuju. Sedangkan model pembelajaran ini sangat setujui dapat meningkatkan konsentrasi dan keterlibatan dalam belajar dari awal sampai akhir secara serius dalam suasana santai sesuai dengan jawaban soal angket sebesar 66,6\% . Dengan membuat puzzle Tabel Periodik Unsur dari steroform pembelajaran ini, peserta didik setuju merasa mendapatkan pengetahuan yang mudah diingat dan berkesan secara mendalam karena dengan praktek ini peserta didik langsung menyusun memori tentang puzzle Tabel Periodik Unsur dari steroform, yang dibuatnya $76,2 \%$. Sebanyak $85,7 \%$ peserta didik setuju juga jika mereka dapat terhindarkan dari kebosanan, tekanan dan ancaman dalam belajar dengan menemukan sesuatu yang baru dalam mempelajari ikatan kimia. Dengan pembelajaran model ini peserta didik menyetujui jika merasa 
diteguhkan bahwa untuk menguasai materi pelajaran diperlukan upaya/jerih payah. Hal ini dibuktikan dari jawaban angket sebesar 66.6\%

Dari pertanyaan tentang diskusi kelompok membuat mereka dapat memperoleh pengetahuan dengan mudah dijawab sebesar $47,6 \%$. Metode ini membuat $42,8 \%$ mendapatkan pengetahuan dengan mudah. Sebesar $57,1 \%$ peserta didik merasa menemukan pengalaman baru dalam belajar. Metode kerjasama diyakini oleh $71 \%$ peserta didik lebih efektif daripada membaca sendiri dan dapat membebaskan peserta didik dari kebosanan. Sedangkan suasana yang menyenangkan dengan media dan metode seperti ini disetujui oleh $80 \%$ peserta didik. Ideide kreatif dan inovatif sangat dinantikan oleh peserta didik dalam belajar materi-materi yang lain. Hal tersebut ditunjukkan oleh jawaban angket sebesar $90 \%$.

Dari kegiatan ini dapat dilihat adanya beberapa hasil yang dicapai. Peningkatan penguasaan konsep. Peningkatan penguasaan konsep ikatan kimia melalui metode praktek membuat puzzle Tabel Periodik Unsur dari steroform dapat dilihat dari hasil nilai test peserta didik. Peningkatan nilai ini membuktikan bahwa pembelajaran dengan menggunakan metode praktek membuat puzzle Tabel Periodik Unsur dari steroform dapat mempermudah peserta didik menguasi materi ikatan kimia. Hal ini disebabkan karena peserta didik membuat sendiri puzzle Tabel Periodik Unsur tersebut, sehingga dalam diri peserta didik terjadi proses merekam obyek yang dipelajarinya. Selama proses membuat puzzle, peserta didik langsung mengingat letak unsur dalam tabel, unsur apa saja yang termasuk logam dan unsur apa saja yang termasuk nonlogam, berapa kemampuan unsur melepas dan menyerap elektron. Dengan demikian, dapat mempermudah peserta didik dalam menentukan unsur apa saja yang bisa membentuk ikatan ion dan ikatan kovalen.

Kemudian dengan diajarkan proses pembentukan ikatan ion melalui serah terima elektron, maka peserta didik tidak kesulitan menentukan unsur apa saja yang bisa terbentuk menjadi senyawa ion. Kemudian dilanjutkan dengan penjelasan tentang penggunaan elektron secara bersama-sama oleh dua atom atau lebih dengan menggunakan Struktur Lewis. Saat menentukan atom apa saja yang bisa berpasangan membentuk ikatan kovalen, peserta didik sudah tidak mengalami kesulitan lagi. Hal ini telah mempermudah peserta didik dalam mengikuti penjelasan tentang ikatan kimia, khususnya ikatan kovalen. Dengan memberikan beberapa contoh, beberapa peserta didik sudah bisa menulis ikatan kovalen. Sudah terjadi "Peneguhan Konsep" dalam diri peserta didik, sehingga peserta didik benar-benar paham tanpa harus membuka buku lagi.

Perubahan Suasana Belajar. Pembelajaran akan berjalan efektif, jika peserta didik berada dalam suasana yang menyenangkan. Pembelajaran menyenangkan menurut Dave Meir dalam buku Menjadi Guru yang Mengajar Secara menyenangkan (2004:17) adalah pembelajaran yang suasana belajarnya dalam keadaan gembira. Suasana pembelajaran yang penuh kegembiraan berarti bangkitnya minat, adanya keterlibatan penuh, serta terciptanya makna, pemahaman (penguasaan atas materi yang dipelajari), dan nilai yang membahagiakan pada diri peserta didik. Metode praktek membuat dan bermain puzzle Tabel Periodik Unsur dari steroform, merupakan pembelajaran yang menyenangkan, dibuktikan dengan tingginya nilai angket peserta didik.

Menurut, Susilowarno (2007), kelebihan penerapan inovasi pembelajaran seperti ini adalah memberi kesempatan peserta didik untuk bertanya, berdiskusi, menyelidiki, bereksperimen dalam suasana yang aktif, inovatif, kreatif, efektif dan menyenangkan. Media pembelajaran yang digunakan dapat memberikan pengalaman konkret, memotivasi peserta didik belajar, serta mempertinggi daya serap dan retensi belajar peserta didik Penerapan metode ini akan dinilai berhasil apabila dihasilkan peserta didik yang terlibat berpikir aktif dalam setiap kegiatan kelas, berani mengajukan pertanyaan dan jawabannya, maupun mengajukan gagasan dan pendapat, mampu dan berani menilai hasil/ membuktikan sesuatu, serta mampu memecahkan masalah yang dihadapinya.

\section{SIMPULAN DAN SARAN Simpulan}

Dari proses kegiatan melaksanakan praktek membuat dan bermain puzzle Tabel Periodik Unsur dari steroform, dapat disimpulkan : (1) Peserta didik belajar aktif, gembira, bekerja sama, saling membantu, saling memacu, berani bertanya dan berani mengajukan pendapat; (2) Peserta didik bisa mengingat dan membedakan unsur logam dan nonlogam, sehingga memudahkan peserta didik 
dalam mengerjakan soal, apakah senyawa pada soal termasuk senyawa ion atau senyawa kovalen; (3) Peserta didik bisa menulis proses terjadinya ikatan ion dan ikatan kovalen, berdasarkan serah terima elektron dan penggunaan sepasang elektron secara bersamasama menggunakan Struktur Lewis; (4) Peserta didik bekerjasama, berlomba, bersaing antar kelompok untuk mendapatkan nilai terbaik; (5) Peserta didik dapat mencapai KKM yang telah ditentukan.

\section{Saran}

Penelitian Tindakan Kelas ini masih jauh dari kata sempurna, oleh sebab itu saran dan kritik yang membangun penelitian selanjutnya sangat diharapkan. Akhirnya, semoga penelitian ini berguna bagi peserta didik, guru dan sekolah.

\section{DAFTAR PUSTAKA}

Abimanyu, Soli dkk. 2008. Strategi Pembelajaran. Jakarta: Depdiknas.

Amri, Sofan dan Iif Khoiru Ahmadi. 2010. Konstruksi Pengembangan
Anitah, Sri, Prof., M.Pd. 2010. Media Pembelajaran. Surakarta: Yuma Pustaka.

Asma, Nur. 2006. Model Pembelajaran Kooperatif. Jakarta: Depdiknas.

McWey, L.M., Henderson, T.L., dan Piercy, F.P. 2006. Cooperative Learning Through Collaborative Faculty-Student Research Teams. Jurnal subject Sociology, Education. 55/2: 252-262.

Sudjana, Nana,Dr. Dan Rivai, Ahmad,Drs. 2009. Media Pembelajaran. Bandung: Sinar Baru Algenssindo

Trianto. 2009. Mendesain Model Pembelajaran Inovatif Progresif: Konsep, Landasan, dan Implementasinya pada Kurikulum Tingkat Satuan Pendidikan (KTSP). Jakarta: Kencana.

Undang-Undang Republik Indonesia Nomor 20 tahun 2003 tentang Sistem Pendidikan Nasionl. 2006. Bandung: Citra Umbara.Sumber:ttps://www.siswapedia.co $\mathrm{m}$

Purba, Michael Drs. Msi dan Sunardi, Drs. Msi. Kimia kelas X (KTSP 2006). 2012. Jakarta Penerbit Erlangga. 